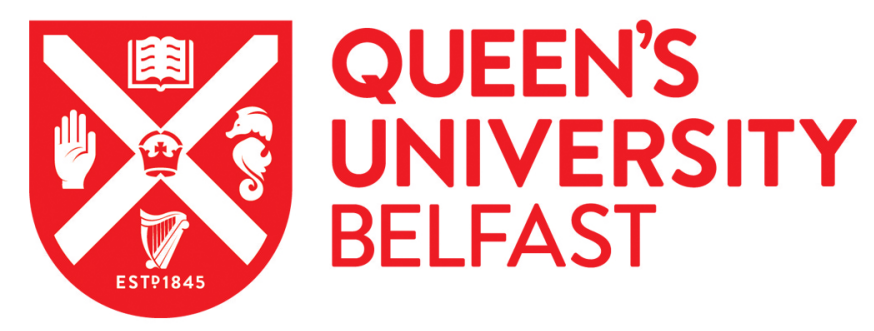

\title{
Meat thermometer usage amongst European and North American consumers: A scoping review
}

Elshahat, S., Woodside, J. V., \& McKinley, M. C. (2019). Meat thermometer usage amongst European and North American consumers: A scoping review. Food Control, 106, [106692].

https://doi.org/10.1016/j.foodcont.2019.06.018

\section{Published in:}

Food Control

\section{Document Version:}

Peer reviewed version

Queen's University Belfast - Research Portal:

Link to publication record in Queen's University Belfast Research Portal

\section{Publisher rights}

Copyright 2019 Elsevier Ltd.

This manuscript is distributed under a Creative Commons Attribution-NonCommercial-NoDerivs License

(https://creativecommons.org/licenses/by-nc-nd/4.0/), which permits distribution and reproduction for non-commercial purposes, provided the author and source are cited.

\section{General rights}

Copyright for the publications made accessible via the Queen's University Belfast Research Portal is retained by the author(s) and / or other copyright owners and it is a condition of accessing these publications that users recognise and abide by the legal requirements associated with these rights.

Take down policy

The Research Portal is Queen's institutional repository that provides access to Queen's research output. Every effort has been made to ensure that content in the Research Portal does not infringe any person's rights, or applicable UK laws. If you discover content in the Research Portal that you believe breaches copyright or violates any law, please contact openaccess@qub.ac.uk. 


\section{Abstract}

Improper cooking of meat contributes to many foodborne illnesses worldwide. The use of meat thermometers during cooking is recommended by food safety authorities in North America, but not yet in Europe. This scoping review investigated meat thermometer usage trends, consumers' barriers and facilitators, and usage-enhancing interventions, with the aim of informing potential policy changes as necessary towards enhancing meat thermometers usage. The study revealed that Europe is far behind North America in meat thermometer research and consumer use. The study results highlighted the increased compliance among mid-aged and higher socio-economic consumer groups. A considerable percentage of people do not use a meat thermometer, despite owning one and knowing its importance. Barriers to meat thermometer usage among consumers included: cooking habits, non-practicality, and the influence of society and media, whereas responsibility to dependents and enhancing meat quality were strong facilitators. Intervention studies showed that knowledge gain does not necessarily translate to behavior change, unless consumers' barriers and facilitators are addressed; hence behavioral theory-based interventions were most effective. The review concludes with recommendations for food safety authorities, starting with filling the research gap to understand consumers' attitudes and behaviors, followed by implementation and scaling-up of evidence-based interventions, associated with cost-effectiveness studies.

Keywords: proper cooking; foodborne illness; intervention; consumers' attitudes; barriers 
Foodborne illness is a major public health problem, which affected $10 \%$ of the world population in 2010, and resulted in almost 420,000 deaths (World Health Organization, 2015). The problem results in about 23 million illnesses in Europe, among which one million cases occur in the UK, resulting in around 500 deaths annually (Food Standards Agency, 2017). About one sixth of Americans, one eighth of Canadians, and one quarter of Australians are affected by foodborne diseases annually (Santacruz, 2016).

Foodborne illnesses are usually linked to improper food-handling practices, such as inadequate cooking, improper storage, and cross-contamination. The top causes of foodborne illnesses in developed countries include Campylobacter, Salmonella, norovirus, Listeria and Escherichia coli O157:H7 (E.coli). Salmonella, Listeria, and E. coli O157:H7 are mainly found in raw or undercooked meat, including beef, poultry, lamb and pork, while Campylobacter is mainly common in poultry products (National Health Services, 2018). Many Salmonella and Campylobacter outbreaks have been linked to the consumption of undercooked poultry products, whereas consumption of undercooked ground (minced) beef or pork has been associated with many E. coli O157:H7 outbreaks (Food Safety Authority of Ireland, 2017a; Moawad et al., 2017; Huusko et al., 2017).

\subsection{Proper cooking procedures and current guidelines}

Cooking meat to a safe temperature is an important prophylactic measure to eliminate harmful pathogens (Maughan, 2015). The safe cooking temperature depends on meat type. The Food Standards Agency (FSA) (2018), and Food Safety Authority of Ireland (FSAI) (2017b) 
recommend cooking meat until the core temperature $\geq 75^{\circ} \mathrm{C}$. On the other hand, the New South Wales (NSW) Food Authority (2018), the US Department of Agriculture (USDA)- Food Safety and Inspection Service (FSIS) (2015a), and Government of Canada (2015) have issued charts for safe minimum cooking temperatures for different meat types (Table 1).

Food safety authorities in Europe recommend cooking meat products until the fulfilment of three visual signs, namely; meat is steaming hot, no longer pink, and juices are running clear (Food Standards Agency, 2018, Food Safety Authority of Ireland, 2017a). However, research findings have revealed that these visual cues are not reliable indicators of safety (Bergsma, Fischer, Van Asselt, Zwietering, and De Jong, 2007; Maughan, 2015)

\subsection{Meat thermometers}

The usage of meat thermometers for identification of the safe cooking temperature has been

Proper usage of thermometers is essential to ensure accurate measurement of meat temperature. Generally, different food safety authorities recommend the thermometer tip to be inserted in the centre of the thickest part of meat, and waiting until a stable temperature is reached (FSIS, 
2011). Core temperature should be measured in several locations, particularly with irregularly shaped cuts of meat. Meat thermometer probes should be properly cleaned before and after each use in order to prevent potential cross-contamination (FSIS, 2011).

The aim of this scoping review of scholarly and grey literature was to map what is known from research about subjects' knowledge, attitudes, and behaviors towards the usage of meat thermometers, to inform recommendations for future research and policy changes as necessary for enhancing meat thermometer usage. To the authors' knowledge, this is the first review focusing on meat thermometers usage across the developed countries. The objectives of this review were (1) to investigate the perceptions and trends in meat thermometers usage among consumers, (2) to analyze the barriers and facilitators to meat thermometers usage, and (3) to explore previously conducted interventions aiming at enhancing meat thermometer usage.

\section{Methodology}

Given the broad nature of the study topic, a scoping review was conducted in order to categorize existing literature in terms of its nature, features and volume. In contrast, systemic review is designed to collect empirical evidence and answer precisely defined, narrow questions. Both methodologies employ systematic search strategies. The scoping review plan of this study followed the six-stage methodological framework developed by Arksey and O’Malley (2005) as follows:

\subsection{Identifying the research question}

A broad research question was set to scope the literature: What is known from literature about the use of meat thermometers to decrease the incidence of foodborne illnesses arising from undercooked meat? 


\subsection{Identification of relevant studies}

A flexible comprehensive search strategy was developed and implemented to locate any relevant literature. The key concepts were identified in the research question, namely, meat thermometers, foodborne illnesses and undercooked meat. A total of 25 search terms were operated through two different combinations using Boolean operators 'AND' and 'OR'. The search procedure included various automated and manual search methods to minimize the chance of missing pertinent information.

The automated search was implemented in four databases, namely, Medline, Embase, Scopus and ProQuest, using the selected search terms. The search process had no date limits in order not to exclude any potentially relevant studies. The search strategy also included bibliographies of potential search results, physically examining journals, researching key authors, theses, and technical reports provided by both governmental and non-governmental organizations.

\subsection{Study selection}

Only English articles were included in the review. Studies were included, if they addressed consumers' meat cooking behaviors, trends of meat thermometer ownership and usage, as well as barriers and facilitators to the usage of meat thermometers. The review also included studies concerned with interventions enhancing meat thermometer usage. The following types of papers were excluded: (1) studies addressing microbiological strains of foodborne pathogens; (2) articles concerned with general food safety practices, and/or proper storage conditions.

Included studies were selected from among the search results in a two-step process, where the titles and abstracts of the search results were first subjected to preliminary screening against the inclusion and exclusion criteria by one author. When there was uncertainty about the eligibility 
for inclusion, the records were saved for further assessment by the other authors in order to minimize the possibility of selection bias. The remaining articles were then re-assessed by reviewing their full text, together with the articles identified through bibliographies and manual web search (Fig. 1). The included sources were cited using reference manager software and duplicates were removed (Mendeley Desktop v1.19.3; Mendeley Ltd, UK).

\subsection{Charting the data}

Data were extracted in standardized forms developed in Microsoft Excel. These included authorship, study title, study objective/aim, study design, study subjects and major findings.

\subsection{Collating, summarizing and reporting of results}

The analysis phase was divided into several steps in order to classify complex data in a way

\subsection{Consultation exercise}

The authors considered consultation with safefood; a governmental administration of food safety in Ireland (Safefood 2018), through a face-to-face meeting between two authors and safefood representative in order to inform and validate the review findings (Tricco et al., 2016). The meeting included presentation of the study aim, objectives, research methodology, and the main themes of the extracted results, followed by mutual discussions and recommendations 
from all participants. The outcomes of the consultation exercise were taken into account during further progress of the study.

\section{Results}

A total of 1009 potential articles were initially retrieved from the searched databases, with an additional 35 sourced from bibliographies and web searches. These were eventually reduced to 75 studies based on the exclusion criteria (Fig. 1). The majority of these studies were conducted in North America (70\% in the US and 13\% in Canada), while the remainder were conducted in the UK, Ireland, the Netherlands, Austria and Malaysia. The median year of publication was 2009 (range 1991- 2018). The three predominant study designs were statistical survey (40\%), combined survey and observation (19\%) and uncontrolled before-after study (16\%). The data

Perceptions and trends in the usage of meat thermometers were classified into three major themes: perceptions and trends in the usage of meat thermometers; barriers versus facilitators to meat thermometer usage; and interventions aiming at enhancing meat thermometers usage.

This theme included 56 studies, which addressed safe food-handling knowledge and behaviors among consumers, with a special focus on the trends in meat thermometers ownership and usage. The studies were classified according to the country of origin: US ( $n=38)$, Canada $(n=7)$, and Europe $(\mathrm{n}=11)$.

\subsubsection{Perceptions and trends in the US}

\subsubsection{The knowledge-compliance and ownership-usage gaps}

Studies revealed low adherence to the usage of meat thermometers, with the presence of a significant 'knowledge-compliance' gap (Table 2). Food safety trained store managers were 
found to lack essential knowledge about food safety, including the safe temperature of different meat types (Rhynard, 2001; Burch and Sawyer, 1991). Direct observation also highlighted a significant meat thermometer 'ownership-usage' gap (Table 2). In the majority of the studies, participants relied on sensory cues, such as meat color and texture, clarity of juices, poking with a utensil, as well as tasting to check doneness of meat (Koeppl, 1998; Teague and Anderson, 1995). Shapiro, Porticella, Jiang, and Gravani et al. (2011) designed a questionnaire to measure participants' intentions to use a meat thermometer based on the theory of planned behavior (TPB), which proposes that individuals' intention to perform a certain behaviour is an effective predictor of the actual behavior. The study revealed that nearly half of respondents disagreed 
Several studies addressed meat thermometer usage with different meat types and found a lower trend of meat thermometer usage with small cuts of meat, compared with large cuts of meat and whole poultry (Table 3). Likewise, studies by Cates, Carter-Young, Durocher, Williams, and Conley (2002b) and Feng, Bruhn, and Marx (2016) revealed that most participants only used meat thermometers with roasts and whole poultry. Despite the low usage with small cuts of meat, Lando and Chen (2012) reported a significant improvement by $20 \%$ and $9 \%$ in the usage of a meat thermometer with chicken parts and hamburgers respectively, over the period 19982010.

\subsubsection{Meat thermometer usage among different groups of consumers}

The trends of meat thermometer ownership and usage varied with age. Meat thermometers usage is generally more common among mid-aged adults (30-59 years), relative to adults of either older or younger ages (Yarrow, 2006; Koeppl, 1998; Lin, 2018; Cates et al., 2009; Cates, Karns, Kosa, and Godwin, 2013). In contrast, Lando and Chen (2012) reported a higher trend of meat thermometers usage for roasts among older adults relative to younger ones. A. L. Anderson, Verrill, and Sahyoun (2011) reported that older adults were significantly more likely to own a meat thermometer than younger adults ( $73 \%$ vs. $67 \%$, respectively).

Concerning the effect of gender on safe food-handling knowledge and practices, several reviews and cross-sectional studies showed that women had poor food safety knowledge and were less likely to own and use a meat thermometer relative to men (Scheule, 2004; Patil, Cates, and Morales, 2005; A. L. Anderson et al., 2011; Lando and Chen, 2012). In contrast, Patil, Morales, Cates, Anderson, and Kendall (2004) reported that males were more likely to adopt poor food safety practices than females. 
Trends in thermometer ownership may also vary among different ethnic subgroups. In a survey by Henley et al. (2015), the percentage of meat thermometers ownership among Caucasian, African-American, Hispanic and Asian participants were 64\%, 56\%, 47\% and 35\%, respectively. A. L. Anderson et al. (2011) reported that non-white participants were less likely to own a meat thermometer relative to white participants (54\% vs. $76 \%$, respectively), although the former were more knowledgeable about the importance of using one.

Education and socioeconomic status were also found to impact thermometer ownership and usage. A. L. Anderson. et al. (2011) analyzed the 2006 US Food and Drug Administration (FDA) Food Safety Survey, and concluded that more educated people were more likely to own a meat thermometer (79\% vs. 69\%, respectively). In contrast, Shapiro et al. (2011) identified education level as a significant negative predictor of the intention to adopt meat thermometer

\subsubsection{Usage of meat thermometers in gatherings/outings}

Koeppl (1998) reported that meat thermometers were mostly used over holidays and special occasions, such as Thanksgiving turkey. In contrast, Yavelak et al. (2018) reported that only $33 \%$ of the tailgaters in five American universities used meat thermometers.

\subsubsection{Usage of meat thermometers on TV shows}


Lack of meat thermometers usage was reported to be a common behavior among celebrity chefs. A content analysis of 100 US TV shows by Maughan, Chambers, and Godwin (2017) showed that $75 \%$ of the shows did not use a meat thermometer or give temperature information for different types of meat. Similar results were reported by Woods (2015) based on $60 \mathrm{TV}$ cooking shows in the US.

\subsubsection{Trends of correct usage of meat thermometers}

Maughan (2015) reported that about 36\% of meat thermometer users failed to insert it correctly while cooking poultry products. In contrast, Bruhn (2014) reported that all the participants who used a meat thermometer (34\% of total 120 participants) knew where to insert it correctly in chicken, except one participant failed to remove the thermometer from its casing. Dedonder et al. (2009) also reported that two of 41 study participants tried to use the meat thermometer with chicken without removing its casing.

\subsubsection{Consumers attitude towards different types of thermometers}

RTI reports $(2002 ; 2004)$ showed that some respondents in the focus group couldn't distinguish

\subsubsection{Perceptions and trends in Canada}


Nesbitt et al. (2014) published a review of 26 Canadian food safety studies, which inferred that, although food safety knowledge among Canadians is good, meat thermometers usage is limited. This good food safety knowledge vs. low meat thermometer usage, or 'knowledge-compliance gap; among Canadian consumers was confirmed by different surveys published during the period 2009-2017, which showed that $>75 \%$ of studies participants reported their awareness of proper cooking instructions, the importance of thorough meat cooking, and the risks associated with consumption of undercooked meat, yet $<30 \%$ of the participants reported using meat thermometers (Ekos Research Associates Inc., 2010, Murray et al., 2017) (Table 2). Nonetheless, Ekos Research Associates Inc. (2010) reported an exceptionally higher trend of meat thermometer usage among immune-compromised individuals (33\%).

\subsubsection{Trends of usage of meat thermometers with different types of meat}

Similar to the US, surveys by Fraser Health and Vancouver Coastal Health (2010), and Murray et al. (2017) reported that higher usage was associated with large cuts of meat, relative to smaller cuts (Table 3$)$.

\subsubsection{Meat thermometer usage among different groups of consumers}

Nesbitt et al. (2009) reported that the urban residents in the Waterloo region were significantly less likely to use meat thermometers than residents in rural areas (12\% vs. $22 \%$, respectively). Concerning the effect of gender on meat thermometer usage, women reported higher usage of meat thermometers relative to men (32\% vs. 26\%, respectively) (Murray et al., 2017).

\subsubsection{Usage of meat thermometers on TV shows}

Meat thermometers were reported to be rarely used by Canadian TV chefs, which is consistent with the trends in the US. A content analysis of 116 TV cooking shows on Food Network 
Canada during 2002-2003, revealed that use of meat thermometers to check meat doneness was only observed eight times, whereas relying on color was three times more frequently (Mathiasen, Chapman, Lacroix, and Powell, 2004).

\subsubsection{Perceptions and trends in Europe}

Redmond and Griffith (2003), and Wright, Canham, and Masrani (2011) published reviews which concluded that most people in the UK and Ireland know that improper cooking is a risk factor, but generally have low awareness of cooking guidelines, and fail to adopt meat thermometer usage. Different surveys conducted among British and Irish consumers revealed a meat thermometer usage trend of only $2-4 \%$, with the majority of British and Irish consumers using subjective methods to determine doneness (Table 2). Redmond and Griffith (2004) reported that about $45 \%$ of Welsh consumers were neutral about the usefulness of meat thermometers. Recent surveys in Ireland showed that food safety is perceived as a risk to health most by those with higher educational attainment, and higher socio-economic status (Safefood, 2012; Corcoran and Porter, 2017). In contrast to the US, Irish women had higher knowledge about food safety compared to men (Safefood, 2012).

Surveys among Dutch consumers by Bergsma et al. (2007) and Fischer et al. (2006) showed

\subsection{Barriers versus facilitators to meat thermometers usage}

This theme included 25 studies, which discussed a total of 20 barriers and 14 facilitators to meat thermometers usage. These barriers and facilitators were classified into six descriptive 


\subsubsection{Confidence and perceived risk}

Five US studies revealed that home cooks, particularly those of older age, had confidence in their own experience to cook meat safely with no need to use meat thermometers, and did not believe that foodborne diseases were likely to affect them (Koeppl, 1998; ORC Macro, 2006; Porticella, Shapiro, and Gravani, 2008; Cates et al., 2002b; Shapiro et al., 2011). Responsibility was a strong facilitator among participants of four different studies who reported that they would use a meat thermometer, if messages assured its importance for the safety of their dependent children or elderly (Koeppl, 1998; Cates et al., 2002b; Takeuchi, 2004; McCurdy et al., 2006). Most participants in four focus group studies highlighted the effect of risk motivation, reporting that assuring that meat thermometers usage is the only reliable way to ensure meat safety would be a powerful facilitator (Takeuchi, Hillers, Edwards, Edlefsen, and McCurdy, 2005b; Cates et al., 2002b; McCurdy et al., 2006; ORC Macro, 2006). Similarly, a case study by Starke, Ralston, Brent, Riggins, and Lin (2002) revealed evidence of a positive association between risk motivation and adhering to cooking guidelines. A TTM-based questionnaire study by Takeuchi, Edlefsen, McCurdy, and Hillers (2005a) revealed that responsibility towards dependent children, and risk motivation were the most common facilitators among $89 \%$ of participants among all SOCs. A focus group study by Porticella et al. (2008) also revealed that increased perceived susceptibility would motivate consumers to adopt meat thermometer usage.

\subsubsection{Knowledge and perception}

Participants in several focus group studies reported that their lack of knowledge about the importance of meat thermometers, and the safe temperatures for different meat types was a perceived barrier to adopting meat thermometers usage (Koeppl, 1998; McCurdy et al., 2006; 

as a possible barrier to meat thermometer usage. Nonetheless, Porticella et al. (2008) reported that knowledge alone did not always lead to meat thermometers usage. This is consistent with the previously mentioned significant gap between levels of knowledge about safe cooking behaviors and actual meat thermometer usage. Koeppl (1998) reported that some focus group participants had false perceptions about the benefits and risks of meat thermometers. While some participants were sceptical about whether using a meat thermometer would guarantee meat safety, others believed that using a meat thermometer might cause a false sense of security during cooking. On the other hand, participants in two focus group studies among US adults recommended that including pictures in educational material packages showing that color is not a reliable indicator would be an effective facilitator (McCurdy et al., 2006; ORC Macro, 2006). Takeuchi et al. (2005a) also reported that the message of "appearance and color are not good indicators of meat doneness" was one of the most effective messages in the intervention that was designed to enhance meat thermometers usage.

\subsubsection{Habits and heuristics}

A focus group study by Koeppl (1998) revealed that many study participants, particularly young

\subsubsection{Practical and lifestyle constraints}


Participants in nine different focus groups studies in the US considered meat thermometer use as inconvenient and/or impractical, particularly while cooking small cuts of meat, cooking individual portions, or grilling large number of hamburgers. Reported barriers in this context included lack of time, laziness, difficult usage, forgetfulness, and labor intensiveness (Koeppl, 1998; Cates et al., 2002b; Takeuchi et al., 2005a; 2005b; Porticella et al., 2008; Takeuchi, 2004; Kosa, Cates, Godwin, and Chambers, 2017; Phang and Bruhn, 2011; McCurdy et al., 2006). Concerning the barriers at different SOC, Takeuchi et al. (2005a) ranked the difficulty of usage as the main barrier, which was reported by $44 \%$ and $33 \%$ of the participants in the preparation and action stages, respectively. This barrier is of importance among older consumers, as they were more likely to have to put their glasses on to be able to read the thermometer (Bruhn, 2014). Furthermore, Takeuchi et al. (2005a) reported that lack of time was identified as a barrier by $15 \%$ of participants across all SOCs. York et al. (2009) reported unfamiliarity, lack of experience, unavailability or inaccessibility among the main barriers to usage of meat thermometers by restaurant chefs. Other studies also attributed the low usage of meat thermometers among consumers to the same barriers (Kosa et al., 2015; Lando and Chen, 2012; Shapiro et al., 2011; DeDonder et al., 2009; Bergsma et al., 2007; Fischer et al., 2006).

Cost of meat thermometers was controversially considered as barrier. Takeuchi et al. (2005a) reported that $9 \%$ of participants across all SOCs identified cost as a potential barrier. A focus group study by Porticella et al. (2008) also identified financial cost as a probable barrier. In contrast, Koeppl (1998) reported that most focus group participants considered thermometer price to be affordable. The cost barrier may be restricted to those with lower incomes, as suggested by both Scheule (2004) and Lando and Chen (2012).

In a TPB-based questionnaire study by Shapiro et al. (2011) developed a TPB-based questionnaire utilizing two constructs; perceived behavioral control and subjective norms. 
The former was concerned with person's perception of the extent to which adopting meat thermometers usage is easy or difficult, and was found to be the most significant predictor of the intention to use a meat thermometer. This was followed by subjective norms, which addressed person's recognition and acceptance of expectations of other people to meat thermometers usage. Participants in several studies reported that they would consider meat thermometer usage if practical constraints were removed, such as if thermometers could save time or be placed easily on thin cuts of meat (Takeuchi et al., 2005b; Koeppl, 1998; ORC Macro, 2006). Takeuchi et al. (2005a) noted that $87 \%$ of participants demonstrated ease of meat thermometer usage as a strong facilitator, yet most participants cited having a reminder posted in their kitchen as the least powerful facilitator. Other authors suggested that increasing the availability of meat thermometers in the market might be a potential facilitator. (Lando and Chen, 2012; Fischer et al., 2006; McCurdy et al., 2006).

\subsubsection{Doneness preference}

While some consumers prefer the taste of undercooked meat, others prefer it well-done or even overcooked. Porticella et al. (2008) and Starke et al. (2002) reported that some participants did not use meat thermometers, due to its perceived negative impact on taste. On the other hand, many participants in other studies indicated that they would consider meat thermometer usage, if it enhanced quality of meat besides improving safety (Koeppl, 1998; Starke et al., 2002; Cates et al., 2002b; Maughan, 2015).

\subsubsection{Social and societal influences}

Koeppl (1998) reported that participants acquired their current cooking behaviors from family members. Takeuchi et al. (2005a) also identified that $81 \%$ of their participants who didn't use a meat thermometer don't know anyone who uses one. Many other studies reported the effect 
of media as a perceived barrier to meat thermometer usage, such as the lack of meat thermometer usage on TV shows and in magazines (Phang and Bruhn, 2011; Shapiro et al., 2011; Mathiasen et al., 2004; Phang, 2010; Woods, 2015; Maughan, 2015; McCurdy et al., 2006). In the same context, appearance and perceived social costs were cited as perceived barriers to meat thermometers usage by most participants in separate studies (Koeppl, 1998; Porticella et al., 2008). Participants in several focus groups studies reported that directing cooks to use a meat thermometer in recipes, cookbooks, food safety labels, as well as TV cooking shows would be a powerful facilitator (Koeppl, 1998; Porticella et al., 2008; McCurdy et al., 2006; Phang and Bruhn, 2011). Takeuchi et al. (2005a) reported that $87 \%$ of participants across all SOC found including temperatures of different meat types with recipes as a strong facilitator. Furthermore, some participants in the focus group studies by both Koeppl (1998) and Porticella et al. (2008) suggested invoking social pressure by conveying the meat thermometer message through celebrities, dieticians, and the government. Participants indicated that they had great concerns with regards to pride in their cooking skills, and that they would use a meat thermometer, if others valued this behavior. In the same studies, participants recommended media stories and in-depth coverage of foodborne illness outbreaks as being powerful motivators for behavioral change.

\subsection{Interventions aiming at enhancing meat thermometers usage}

This theme included a total of 20 studies utilizing various interventions to improve meat thermometer usage among consumers through increasing knowledge (12 studies) and addressing attitudes (14 studies) towards thermometer usage. The interventions varied between using educational materials, training programs, campaigns, mixed approaches using different intervention types, temporary closure of restaurants in response to poor food safety practices, advising thermometer usage in recipes, as well as positive deviance focus groups, which is a 
novel educational intervention where participants discuss their current practices and decide to try adopting the recommended behaviors modelled by people like themselves.

\subsubsection{Educational materials}

Takeuchi (2004) and Takeuchi et al. (2005a) applied the TTM to evaluate an educational intervention among 2500 randomly selected American consumers, who were distributed among the five different SOCs. Educational material packages comprised a brochure, a video, recipe cards and a refrigerator magnet, but without meat thermometer. The study revealed that the educational materials resulted in a significant increase in thermometer ownership (from 34 to $42 \%$ ), and usage (from 4 to $16 \%$ ). The proportion of participants in the precontemplation stage significantly decreased from 80 to $46 \%$, meaning there was a significant increase total proportion of participants who were in the preparation, action or maintenance stages from 12 to $41 \%$. In another study, Takeuchi et al. (2005b) used a similar educational package to assess the impact of each element of the package on enhancing meat thermometers usage. The brochure was the most effective component, which motivated $63 \%$ of participants, followed by recipe cards $(45 \%)$ and the video $(38 \%)$. The brochure was particularly useful for those in the precontemplation and contemplation stages, whilst participants in the action and maintenance stages found the video most useful.

Edwards, Edlefsen, Hillers, and McCurdy (2005) used a teaching kit including the materials designed by Takeuchi et al. (2005a) to target 326 American high school students, yet additional items were included in the kit (four 50-min teaching lessons, handouts, homework activities, four posters and an instant-read digital thermometer). These were utilized by students through both theoretical and practical classes, allowing students to know about the importance of adopting thermometers usage, besides giving them the chance to use one. The pre- and post- 
intervention surveys revealed that the students' mean knowledge score significantly increased by 2.7 , with $42 \%$ of the students reporting an increase in their confidence in using a meat thermometer. The mean SOC score significantly increased from 2.3 to 2.6 , with $30 \%$ of the students making progress toward a higher SOC. Later on, McCurdy et al. (2006) published a study with similar findings. The evaluation report of Pathogen Reduction, Hazard Analysis and Critical Control Point System (PR/HACCP) published by the RTI (2002) mentioned using the same educational materials among six groups of parents of young children, among whom, participants of only three groups received meat thermometers. After a one-month intervention, surveys revealed that $63 \%$ of participants who received a meat thermometer reported that they

\subsubsection{Food safety training} began to use one, compared to only $13 \%$ of those who did not receive one. Moreover, 50 and $42 \%$ of those who received a thermometer used it with chicken pieces and hamburger, respectively, compared to only 22 and $0 \%$ of those who did not receive one.

Six studies investigated the effect of food safety training on the knowledge, attitudes and behavioral compliance with safe cooking practices among both catering and domestic consumers. Robert et al. (2008) held a four-hour food safety training covering three food safety practices, including meat thermometer usage for 402 foodservice employees in the US. The post-training assessment showed a significant improvement in knowledge scores related to proper thermometer usage, yet with no significant improvement in adopting meat thermometer usage. Surprisingly, Pilling et al. (2008) reported that food workers in restaurants where training was mandatory for all food handlers had significantly lower knowledge score about food safety compared to those working in restaurants where only managers were knowledgeable about food safety (12.8 vs. 14.3 out of 18 , respectively). However, there was no significant difference between the two groups in terms of compliance with meat thermometer usage. A four-hour 
TPB-based training among food workers in 16 Malaysian school canteens also failed to increase participants' knowledge about using thermometers while cooking (Nik Husain, Wan Muda, Noor Jamil, Nik Hanafi, and Abdul Rahman, 2016). The failure of this intervention may be attributed to its focus on covering the concept without providing a meat thermometer to the canteen workers during the training. In contrast, McIntyre (2011) showed that trained food safety workers in British Columbia used meat thermometers more often than untrained workers. Finch and Daniel (2005) also showed that food safety training of 267 food handlers working at emergency food relief organizations in New York State increased meat thermometers usage among handlers, and significantly improved participants' knowledge. On comparing different types of food safety training, Yeung (2014) showed that both web-based training and workshops for 110 American participants improved their knowledge about the importance of cooking meat to its safe temperature.

\subsubsection{Campaigns}

Several campaigns have been conducted by food safety authorities in the US to address

Cody and Hogue (2003) examined the impact of the "FightBAC" campaign. Post-campaign 
consumers reported using meat thermometers. Kosa and Cates (2004) assessed the effectiveness of the "Is it DONE yet?" campaign, where they reported an increase in participants' knowledge, ownership and frequent usage of meat thermometers.

\subsubsection{Mixed approach}

The FSIS (1996) published the PR/HACCP final rule with the aim of reducing the risk of foodborne diseases. This was followed by PR/HACCP farm-to-table initiatives, which included education campaigns, promoting farm-to-fork strategies, and training of food handlers (Institute of Medicine and National Research Council (US) Committee 1998). Cates, Kosa, and CarterYoung (2002a) analyzed the US FDA Food Safety Surveys (1998-2001) to assess the effectiveness of PR/HACCP farm-to-table initiatives. Consumers demonstrated increased knowledge, with increase in meat thermometer ownership from 46 to $60 \%$ during the period 1998-2001. During the same period, meat thermometer usage increased from 22 to $32 \%$ with large cuts of meat, from 6 to $12 \%$ with chicken pieces, and from 3 to $6 \%$ with hamburgers.

Yavelak et al. (2018) assessed the usefulness of combining positive deviance interventions and educational materials with meat thermometer provision for food handlers working in temporary food settings. Follow-up observation and surveys showed that there was a significant increase in the number of participants using meat thermometers more frequently.

\subsubsection{Comparing different types of interventions}

Feng et al. (2016) compared the effectiveness of three different intervention types (positive deviance with meat thermometers provision, standard educational materials without meat thermometers, and story-based materials) among 182 US adults. Post-intervention evaluation revealed that the three intervention types significantly increased participants' knowledge about 
correct cooking temperatures of different meat types. The active discussions resulted in higher knowledge gain compared to the other intervention types. Participants who were involved in the active discussions reported higher self-efficacy of meat thermometers usage relative to the other interventions.

York et al. (2009) compared the usefulness of two approaches in food service establishments in the US using four different groups of workers receiving either standard food safety training, a TPB-based intervention program, both interventions, or none of them. The participants in the combined training and TPB-based intervention group had better compliance with meat thermometers usage than those in the training and control group. Those who received the combined intervention had significantly higher control over barriers to meat thermometer usage

\subsubsection{Other methods to enhance meat thermometers usage}

Maughan (2015) investigated the usefulness of including meat cooking temperatures in than those in the training and control groups.

different poultry recipes via direct observation. A total of 155 participants were randomly allocated into two groups: with or without food safety instructions. Participants who received recipes with food safety instructions were significantly more likely to use meat thermometers while cooking either chicken pieces ( $85 \%$ vs. $30 \%)$ or turkey burgers $(86 \%$ vs. $20 \%)$. About $58 \%$ of those who used meat thermometers among the instructed group were able to insert it correctly in chicken pieces compared to only $16 \%$ of the non-instructed group. Similar results were obtained on evaluating proper insertion of thermometer in turkey burgers $(76 \%$ vs. $13 \%$ for instructed vs. non-instructed groups, respectively). On the other hand, Mandarino (2017) reported that temporary closure of Canadian restaurants with improper food-handling practices 
did not improve the employees' practices, and food workers continued to demonstrate low thermometer usage.

\subsection{Consultation exercise}

The Safefood representative supported the study findings, advising that many European consumers lack knowledge about safe food-handling practices, including meat thermometer usage. The Safefood representative's input contributed to making sensible recommendations for Europe, and offered helpful guidance for determining next research steps and eventually triggering a process of changing cooking guidelines in Ireland towards recommending meat thermometers usage. This process is expected to be gradual, passing through conducting surveys and focus groups to investigate meat thermometers ownership and usage, and barriers as well as facilitators to meat thermometers usage. Future steps would also include increasing consumers' awareness about the importance of using meat thermometers.

\section{Discussion}

This scoping review aimed to make recommendations for future research, and to inform necessary policy change of cooking guidelines towards promoting meat thermometers usage. The results of this study highlighted the low or improper usage of meat thermometers among both domestic and catering consumers worldwide. Although surveys in the US and Canada showed relatively high awareness about food safety practices among consumers, with the majority owned a meat thermometer, consumers reported low thermometer usage, revealing both ownership-usage and knowledge-compliance gaps. The usage trends were even lower when observing consumers' cooking practices, indicating possible social desirability bias and response bias (Redmond and Griffith, 2003). Therefore, we believe that the results of direct observation studies are more reliable than the survey results, although the observation process 
still sometimes influences the participants' behavior, leading to false reporting of compliance (Redmond and Griffith, 2003; Yavelak et al., 2018). Nonetheless, we identified a notable increase in the ownership and usage of meat thermometers over time in Canada and the US, which may be attributed to the different public health interventions and campaigns conducted by food safety authorities in both countries.

The review produced limited meat thermometer ownership/usage data from Europe, which suggested that meat thermometer usage was not a common food safety practice among European consumers. The reported low usage of meat thermometers in the UK and Ireland may be attributed to the lack of guidelines explicitly recommending their use in both countries (FSA, 2018; FSAI, 2017a).

Direct observation, surveys, and focus groups indicated that meat thermometer usage differs among consumers according to their gender, age, ethnicity, level of education, socio-economic status, environment, and social norms. In spite of some inconsistencies, seniors (60+ years) generally exhibit resistance to adopt behavioral change and young adults ( $<30$ years) exhibit low perceived risk of foodborne illnesses. Practicality is also a major concern for many consumers, where consumers find thermometer use inconvenient with smaller cuts of meat, which justifies the observed gap between thermometer usage with chicken pieces and hamburgers, compared to usage with large cuts of meat and whole poultry. Focusing on cooking time and other visual methods in popular sources such as magazine recipes and TV cooking shows contributed to a general feeling among consumers that using a meat thermometer while cooking contradicts with social norms.

Comparison of the effectiveness of different interventions developed in the US for enhancing meat thermometers usage revealed that the interventions based on behavior change theories were most effective. Educational materials and campaigns designed to address the perceived 
barriers and facilitators to meat thermometers usage were effective in terms of enhancing usage among different types of consumers (e.g. adults, students, and foodservice employees). Active discussions with consumers were likely to improve consumers' attitudes and intentions, as well as induce behavioral change, particularly if combined with supportive educational materials. Conveying the thermometer usage message through recipes was also found to be effective in terms of behavioral change. In contrast, food safety training seems to be effective only in terms of improving foodservice workers' knowledge, but it had a little impact on their behaviors. These findings confirm that knowledge gain is not necessarily translated to adopting the recommended behaviors, and that addressing the perceived barriers and facilitators through evidence-based interventions is crucial to induce behavioral change among consumers (Patil et al., 2005).

We identified the presence of obvious gaps in research in Australia and continental Europe, and, to a lower extent, in the UK and Ireland, with regards to investigating meat thermometer ownership and usage, as well as barriers to and facilitators of using meat thermometers among consumers. Although many studies in both the US and Canada investigated the effects of different interventions on enhancing meat thermometers usage, the Canadian interventions relied on addressing barriers and facilitators extracted from other US studies, as a result of the lack of studies investigating consumers' perceptions in the Canadian community.

\section{Study limitations}

While a comprehensive approach was adopted for scoping of various sources in order to address the research question in a robust way, some limitations still exist. A potential limitation is that only English articles were reviewed and included, due to financial constraints for translation. This posed a possibility of missing potential articles from non-English speaking countries. The limited literature available from Europe also posed a limitation of not reflecting 
the cultural and ethnic difference among European consumers. As a result of being a relatively under-researched area with a limited number of sources, the authors did not assess the evidence quality in order to include a broader range of evidence from both scientific and grey literature, avoid missing any potentially important documents, and to identify gaps in research to develop recommendations for future research.

\section{Recommendations and conclusions}

Based on the results of this scoping review, we recommend the following steps to enhance meat thermometers use among consumers in order to improve population health worldwide:

1. Conduct surveys and direct observation studies to investigate ownership and usage of meat thermometers (e.g. considering differences by gender, socioeconomic status, age, ethnicity, and in domestic and catering environments) utilizing well-validated TTM and/or TPBbased questionnaires.

2. Conduct qualitative research among consumers, utilizing appropriate behavioral theories, such as TTM and/or TPB as conceptual framework, in order to understand perceptions, attitudes, barriers and facilitators to meat thermometers usage in specific populations and population sub-groups.

3. Based on evidence from 1 and 2 above, design evidence-based interventions to promote meat thermometer usage, with testing in feasibility studies before wider exposure, and evaluate such interventions using validated questionnaires conducted pre- and postintervention.

4. Scale up the interventions showing the most significant improvements in inducing behavior change.

5. Track incidence rates of foodborne illnesses in specific areas where interventions are being implemented. 
6. Conduct cost-effectiveness studies evaluating the costs involved in promoting meat thermometer usage vs. anticipated decrease in the economic burden of foodborne illnesses.

We also recommend the following actions to be adopted by food safety authorities to promote thermometer usage among both domestic and catering consumers:

1. Establish of partnerships with food safety authorities in the US to benefit from the four decades of US experience in conducting campaigns promoting of meat thermometer usage.

2. Ensure the availability of affordable types of meat thermometers in both urban and rural areas.

3. Encourage media (e.g. T.V cooking shows, recipes and magazines) to model and normalize meat thermometers usage and convey the thermometer message in recipes.

4. Urge food manufacturers to print the safe minimum cooking temperatures and thermometer advice on raw meat package labels.

5. Urge industrial and commercial settings to promote meat thermometer use in different ways, such as offering discount coupons for meat thermometers users, tracing domestic usage of meat thermometers through mobile applications, providing disposable thermometers with raw meat packaging...etc.

6. Conduct regular inspections in food service establishments to ensure adherence to the recommended cooking guidelines, including meat thermometers usage.

7. Include meat thermometers usage in the rating criteria of restaurants, and urge restaurants to declare to the public that they are using meat thermometers.

8. Encourage schools to focus on meat thermometers use in students cooking activities.

In conclusion, this review revealed low meat thermometer usage in the developed countries, particularly in Europe. Lack of knowledge does not appear to be the main barrier to meat 
thermometers usage. Instead, the low usage may be attributed to consumers' negative perceptions and attitudes. Educational interventions addressing both consumers' knowledge and attitudes were more effective in changing consumers' behaviors, compared to those concerned only with addressing knowledge. Therefore, food safety authorities worldwide should focus on investigating consumers' beliefs and attitudes towards meat thermometers usage, in order to design effective tailored interventions.

\section{Acknowledgement:}

The authors thank safefood for their consultation of this study, particularly Linda Gordon (Chief Specialist in Food Science at safefood).

Funding:

This research did not receive any specific grants from funding agencies in the public, commercial, or not-for-profit sectors.

\section{Declaration of interest:}

The authors declare no conflict of interest.

References:

Anderson, A. L., Verrill, L. A., and Sahyoun, N. R. (2011). Food safety perceptions and practices of older adults. Public Health Rep, 126 (2): 220-27. http://doi.org/10.1177/003335491112600213.

Anderson, J. B., Shuster, T. A., Hansen, K. E., Levy, A. S., and Volk, A. (2004). A camera's view of consumer food-handling behaviors. J Am Diet Assoc, 104 (2): 186-91. http://doi.org/10.1016/j.jada.2003.11.010.

Arksey, H., and O’Malley, L. (2005). Scoping studies: Towards a methodological framework. 
Int J Soc Res Methodol, 8 (1): 19-32. http://doi.org/10.1080/1364557032000119616.

Bates, B., Hovard, P., Sal, N., and Eaton, E. The Food \& You - Survey Wave 4. (2017). https://www.food.gov.uk/sites/default/files/media/document/food-and-you-w4-devreport.pdf/ Accessed 22 July 2018.

Bergsma, N. J., Fischer, A. R. H., Van Asselt, E..D., Zwietering, M. H., and De Jong, A. E. I. (2007). Consumer food preparation and its implication for survival of Campylobacter jejuni on chicken. Br Food J, 109 (7): 548-61. http://doi.org/10.1108/00070700710761536.

Bruhn, C. M. (2014). Chicken preparation in the home: An observational study. Food Prot Trends, 34 (5): 318-30.

Burch, N. L., and Sawyer, C. A. (1991). Food handling in convenience stores: The impact of personnel knowledge on facility sanitation. Environ Health, 54 (3): 23-27.

Byrd-Bredbenner, C., Maurer, J., Cottone, E., Clancy, M., and Wheatley, V. (2007).

Observed food safety behaviours of young adults. Br Food J, 109 (7): 519-30. http://doi.org/10.1108/00070700710761518.

Cates, S. C., and Anderson, D. W. Thermometer slogan focus group study. Research Triangle Institute. (1999). https://www.fsis.usda.gov/wps/wcm/connect/44d45cb7-8633-4026bde4-433a970cf70e/tslogans.pdf?MOD=AJPERES/ Accessed 22 July 2018.

Cates, S. C., Kosa, K. M., and Carter-Young, H. L. (2002a). Focus groups on changes in consumer knowledge, behavior, and confidence since the 1996 PR/HACCP final rule. Prepared for the U.S. Department of Agriculture, Food Safety and Inspection Service. https://www.fsis.usda.gov/wps/wcm/connect/d3ca3980-f6b4-4ddd-822a-

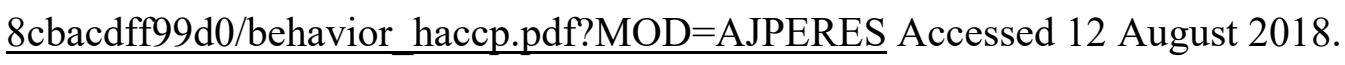


Caes, S. C., Carter-Young, H. L., Durocher, B. L., Williams, C., and Conley, S. (2002b). Thermometer usage messages and delivery mechanisms for parents of young children. Prepared for the U.S. Department of Agriculture, Food Safety and Inspection Service. https://www.fsis.usda.gov/wps/wcm/connect/a7cba75f-dc73-431d-b445-

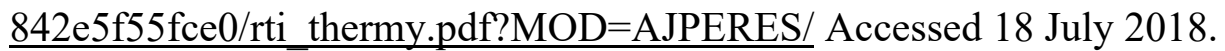

Cates, S. C., Kosa, K. M., Karns, S., Godwin, S. L., Speller-Henderson, L., Harrison, R., and Draughon, F. A. (2009). Food safety knowledge and practices among older adults: Identifying causes and solutions for risky behaviors. J Nutr Elder, 28 (2): 112-26. http://doi.org/10.1080/01639360902949986.

Cates, S. C., Karns, S., Kosa, K. M., and Godwin, S. L. (2013). Predictors of eating raw or undercooked meat, poultry, seafood, and eggs among older adults. Food Prot Trends, 33 (2): 64-72.

Cody, M. M., and Hogue M. A. (2003). Results of the home food safety - It's in your hands 2002 survey: Comparisons to the 1999 benchmark survey and healthy people 2010 food safety behaviors objective. J. Acad. Nutr. Diet., 103 (9): 1115-25. http://doi.org/10.1016/S0002-8223(03)01064-2.

Corcoran, A., and Porter, R. Safetrak Research. Safefood. (2017). http://www.safefood.eu/SafeFood/media/SafeFoodLibrary/Documents/Publications/Mar ket Research/16-088947-Safetrak-Research-Web-Version_FINAL.pdf/ Accessed 3 July 2018.

Courtney, S. (2017). Food safety attitudes and self-reported behaviours of undergraduate students at the University of Waterloo (Ontario, Canada) (Master's thesis, University of Waterloo), Retrieved from: https://uwspace.uwaterloo.ca/bitstream/handle/10012/12439/Courtney_Sarah.pdf?seque 
$\underline{\text { nce }=5}$.

DeDonder, S., Jacob, C. J., Surgeoner, B. V., Chapman, B., Phebus, R., and Powell, D. A. (2009). Self-reported and observed behavior of primary meal preparers and adolescents during preparation of frozen, uncooked, breaded chicken products. Br Food J, 111 (9): 915-29. http://doi.org/10.1108/00070700910992844.

DeDonder, S. E. (2012). Assessment and validation of on-package handling and cooking instructions for raw, breaded poultry products to promote consumer practices that reduce the risk of foodborne illness (PhD thesis, Kansas State University) Retrieved from: http://krex.k$\underline{\text { state.edu/dspace/bitstream/handle/2097/13630/SarahDeDonder2012.pdf? sequence }=1 \& \text { is }}$ Allowed $=\mathrm{y}$.

Edwards, Z., Edlefsen, M., Hillers, V., and McCurdy, S. M. (2005). Evaluation of a teaching Kit for family and consumer science classrooms: Motivating students to use a food thermometer with small cuts of meat. J. Food Sci. Education, 4 (3): 47-52.

Ekos Research Associates Inc. Survey of Canadians' knowledge \& behaviour related to food safety. (2010). http://www.ekospolitics.com/articles/01710.pdf/ Accessed 3 September 2018.

Feng, Y., Bruhn, C., and Marx, D. (2016). Evaluation of different food safety education interventions. Br Food J, 118 (4): 762-76. http://doi.org/10.1108/BFJ-10-2015-0372.

Finch, C., and Daniel, E. (2005). Food safety knowledge and behavior of emergency food relief organization workers: Effects of food safety training intervention. J Environ Health, 67 (9): 30-34.

Fischer, A. R. H., Frewer, L. J., and Nauta, M. J. (2006). Toward improving food safety in 
the domestic environment: A multi-item rasch scale for the measurement of the safety

efficacy of domestic food-handling practices. Risk Anal., 26 (5): 1323-38.

http://doi.org/10.1111/j.1539-6924.2006.00813.x.

Food and Drug Administration. 2016 FDA Food Safety Survey. (2016).

https://www.fda.gov/downloads/food/foodscienceresearch/consumerbehaviorresearch/uc m529453.pdf/ Accessed 15 August 2018.

FSIS. Pathogen Reduction; Hazard Analysis and Critical Control Point (HACCP) systems; final rule. (1996). https://www.fsis.usda.gov/wps/wcm/connect/e113b15a-837c-46af8303-73f7c11fb666/93-016F.pdf?MOD=AJPERES/ Accessed 19 August 2018.

FSIS. Kitchen thermometers. (2011). https://www.fsis.usda.gov/wps/wcm/connect/d8151061bb50-46db-b87e-a3b9022c0c56/Kitchen Thermometers.pdf?MOD=AJPERES/ Accessed 29 July 2018.

FSIS. Safe minimum internal temperature chart. (2015a). https://www.fsis.usda.gov/wps/portal/fsis/topics/food-safety-education/getanswers/food-safety-fact-sheets/safe-food-handling/safe-minimum-internal-temperaturechart/ct index/ Accessed 10 January 2019.

FSIS. Thermy. (2015b). https://www.fsis.usda.gov/wps/portal/fsis/topics/food-safetyeducation/teach-others/fsis-educational-campaigns/thermy/ Accessed 19 August 2018.

FSIS. Is it done yet? (2016). https://www.fsis.usda.gov/wps/portal/fsis/topics/food-safetyeducation/teach-others/fsis-educational-campaigns/is-it-done-yet/ Accessed 19 August 2018.

Food Safety Authority of Ireland. Campylobacter. (2017a). https://www.fsai.ie/faq/campylobacter.html/ Accessed 28 July 2018. 
Food Safety Authority of Ireland. Home cooking and storage. (2017b). https://www.fsai.ie/faq/domestic.html/ Accessed 19 July 2018.

Food Standards Agency. Consolidated annual report and accounts 2017/18. (2017). https://www.food.gov.uk/sites/default/files/media/document/fsa-annual-report-accounts2017-18-consolidated.pdf/ Accessed 21 July 2018.

Food Standards Agency. Safe method: Cooking safely - Thorough cooking kills harmful bacteria. (2018). https://www.food.gov.uk/sites/default/files/media/document/cookingsafely.pdf/ Accessed 19 July 2018.

Fraser Health, and Vancouver Coastal Health. Food safety practices - Findings from a Fraser Health (FH) and Vancouver Coastal Health (VCH) survey. (2010). http://www.fraserhealth.ca/media/Food Safety Practices.pdf/ Accessed 20 July 2018.

Government of Canada. Safe internal cooking temperatures. (2015).

https://www.canada.ca/en/health-canada/services/general-food-safety-tips/safe-internalcooking-temperatures.html/ Accessed 21 July 2018.

Henley, S. C., Stein, S. E., and Quinlan, J. J. (2015). Characterization of raw egg and poultry handling practices among minority consumers: Identification of unique practices. $\mathrm{Br}$ Food J, 117 (12): 3064-75. http://doi.org/10.1108/BFJ-03-2015-0089.

Hoelzl, C., Mayerhofer, U., Steininger, M., Brüller, W., Hofstädter, D., and Aldrian, U. (2013). Observational trial of safe food handling behavior during food preparation using the example of Campylobacter spp. J. Food Prot., 76 (3): 482-89. http://doi.org/10.4315/0362-028X.JFP-12-231.

Huusko, S., Pihlajasaari, A., Salmenlinna, S., Sõgel, J., Dontšenko, I., De Pinna, E., ... Rimhanen-Finne, R. (2017). Outbreak of Salmonella enteritidis phage type 1B 
associated with frozen pre-cooked chicken cubes, Finland 2012. Epidemiol. Infect., 145

Institute of Medicine and National Research Council (US) Committee. Food safety from farm to table: A national food-safety initiative - A report to the president May 1997. In: Ensuring safe food: From production to consumption. Washington (DC): National Academies Press (US). (1998). https://www.ncbi.nlm.nih.gov/books/NBK209117/ Accessed 1 September 2018.

Kendall, P. A., Elsbernd, A., Sinclair, K., Schroeder, M., Chen, G., Bergmann, V., Hillers, V. N., and Medeiros, L. C. (2004). Observation versus self-report: Validation of a consumer food behavior questionnaire. J. Food Prot., 67 (11): 2578-86. http://doi.org/10.4315/0362-028X-67.11.2578.

Kennedy, J., Jackson, V., Blair, I. S., McDowell, D. A., Cowan, C., and Bolton, D. J. (2005). Food safety knowledge of consumers and the microbiological and temperature status of their refrigerators. J. Food Prot., 68 (7): 1421-30. http://doi.org/10.4315/0362-028X$\underline{68.7 .1421 .}$

Koeppl, P. T. Focus groups on barriers that limit consumers' use of thermometers when cooking meat and poultry products - Phase one. (1998). http://www.fsis.usda.gov/wps/wcm/connect/864f3868-f35c-44d6-a1f495c3700d3cca/focusgp.pdf?MOD=AJPERES/ Accessed 15 August 2018.

Kosa, K. M., and Cates, S. C. Focus groups to test materials for the 'Is it done yet?' campaign. Vol. 1. (2004). https://www.fsis.usda.gov/wps/wcm/connect/d99c200a-bc4a40ec-9beb-729c65215f83/FocusGroup_Report_IsItDoneYet.pdf?MOD=AJPERES/ Accessed 13 August 2018.

Kosa, K. M., Cates, S. C., Bradley, S., Chambers, E., and Godwin, S. (2015). Consumer- 
reported handling of raw poultry products at home: Results from a national survey. $J$. Food Prot., 78 (1): 180-86. http://doi.org/10.4315/0362-028X.JFP-14-231.

Kosa, K. M., Cates, S. C., Godwin, S., and Chambers, E. (2017). Barriers to using a food thermometer when cooking poultry at home: Results from a national survey. Food Prot Trends, 37 (2): 116-25.

Lacroix, B. J., Li, K. W. M., and Powell, D. A. (2003). Consumer food handling recommendations: Is thawing of turkey a food safety issue? Can J Diet Pract Res, 64 (2): 59-61. http://doi.org/10.3148/64.2.2003.59.

Lando, A. M., and Chen, C. C. (2012). Trends in ownership and usage of food thermometers in the United States, 1998 through 2010. J. Food Prot., 75 (3): 556-62. http://doi.org/10.4315/0362-028X.JFP-11-314.

Lin, C-T. J. (2018). Self-reported methods used to judge when a hamburger is ready at-home in a sample of U.S. adults. Food Control, 91: 181-84. http://doi.org/10.1016/j.foodcont.2018.03.042.

Mahon, D., Cowan, C., Henchion, M., and Fanning, M. (2006). Food-handling practices of Irish beef consumers. J. Food Saf., 26 (1): 72-81. http://doi.org/10.1111/j.17454565.2005.00028.x.

Mandarino, P. (2017). Temporary restaurant closures and food handling violations: Inspection reports in British Columbia (PhD thesis, Walden University) Retrieved from: https://scholarworks.waldenu.edu/cgi/viewcontent.cgi $?$ article $=4903 \&$ context $=$ dissertatio ns.

Mathiasen, L. A., Chapman, B., Lacroix, B. J., and Powell, D. (2004). Spot the mistake: Television cooking shows as a source of food safety information. Food Prot Trends, 24 
Maughan, C. A. J. (2015). Making preparation of poultry and eggs safer for consumers: A focus on recipes and temperature ( $\mathrm{PhD}$ thesis, Kansas State University) Retrieved from: https://krex.kstate.edu/dspace/bitstream/handle/2097/20538/CurtisMaughan2015.pdf?sequence=1.

Maughan, C., Chambers, E., and Godwin, S. (2017). Food safety behaviors observed in celebrity chefs across a variety of programs. J. Public Health, 39 (1): 105-12. http://doi.org/10.1093/pubmed/fdw026.

Mazengia, E., Fisk, C., Liao, G., Huang, H., and Meschke, J. (2015). Direct observational study of the risk of cross-contamination during raw poultry handling: Practices in private homes. Food Prot Trends, 35 (1): 8-23.

McArthur, L. H., Holbert, D., and Forsythe III, W. A. (2007). College students and awareness of food safety. J Fam Consum Sci, 99 (1): 60-67.

McCurdy, S. M., Takeuchi, M. T., Edwards, Z. M., Edlefsen, M., Kang, D-H., Mayes, V. E., and Hillers, V. N. (2006). Food safety education initiative to increase consumer use of food thermometers in the United States. Br Food J, 108 (9): 775-94. http://doi.org/10.1108/00070700610688403.

Mcintyre, L. Knowledge, practices and attitudes of certified FOODSAFE food handlers - Is retraining needed ? CDC British Columbia. (2011). http://www.bccdc.ca/resourcegallery/Documents/Statistics and Research/Statistics and Reports/EH/FPS/FOODSAFEKnowledgeRetentionProject_FinalSep2011.pdf/ Accessed 13 August 2018.

Moawad, A. A., Hotzel, H., Awad, O., Tomaso, H., Neubauer, H., Hafez, H. M., and El- 
Adawy, H. (2017). Occurrence of Salmonella enterica and Escherichia coli in raw chicken and beef meat in Northern Egypt and dissemination of their antibiotic resistance markers. Gut Pathog, 9 (57). http://doi.org/10.1186/s13099-017-0206-9.

Murray, R., Glass-Kaastra, S., Gardhouse, C., Marshall, B., Ciampa, N., Franklin, K., ... Nesbitt, A. (2017). Canadian consumer food safety practices and knowledge: Foodbook study. J. Food Prot., 80 (10): 1711-18. http://doi.org/10.4315/0362-028X.JFP-17-108.

National Health Services. Food poisoning. (2018). https://www.nhs.uk/conditions/foodpoisoning/ Accessed 18 July 2018.

Nesbitt, A., Majowicz, S., Finley, R., Marshall, B., Pollari, F., Sargeant, J., ... Sittler, N. (2009). High-risk food consumption and food safety practices in a Canadian community. J. Food Prot., 72 (12): 2575-86. https://doi.org/10.4315/0362-028X-72.12.2575.

Nesbitt, A., Thomas, M. K., Marshall, B., Snedeker, K., Meleta, K., Watson, B., and Bienefeld, M. (2014). Baseline for consumer food safety knowledge and behaviour in Canada. Food Control, 38 (1): 157-73. http://doi.org/10.1016/j.foodcont.2013.10.010.

Nik Husain, N. R., Wan Muda, W. M., Noor Jamil, N. I., Nik Hanafi, N. N., and Abdul Rahman, R. (2016). Effect of food safety training on food handlers' knowledge and practices. Br Food J, 118 (4): 795-808. http://doi.org/10.1108/BFJ-08-2015-0294.

NSW Food Authority. Cooking temperatures. (2018). http://www.foodauthority.nsw.gov.au/foodsafetyandyou/food-at-home/cookingtemperatures/ Accessed 19 July 2018.

ORC Macro. United States Department of Agriculture focus group report on creative concept testing for food safety mass media campaign. (2006). https://www.fsis.usda.gov/wps/wcm/connect/3f8bfd3f-f341-4eee-b45f- 
Partnership for Food Safety Education. Fight Bac! (2018). http://www.fightbac.org/ Accessed 19 August 2018.

Patil, S. R., Morales, R., Cates, S., Anderson, D., and Kendall, D. (2004). An application of meta-analysis in food safety consumer research to evaluate consumer behaviors and practices. J. Food Prot., 67 (11): 2587-95. http://doi.org/10.4315/0362-028X$\underline{67.11 .2587 .}$

Patil, S. R., Cates, S., and Morales, R. (2005). Consumer food safety knowledge, practices, and demographic differences: Findings from a meta-analysis. J. Food Prot., 68 (9): 1884-94. http://doi.org/10.4315/0362-028X-68.9.1884.

Phang, H. (2010). Consumer handling of hamburgers (Master's thesis, University of California).

Phang, H. S., and Bruhn, C. M. (2011). Burger preparation: What consumers say and do in the home. J. Food Prot., 74 (10): 1708-16. http://doi.org/10.4315/0362-028X.JFP-10$\underline{417}$.

Pilling, V. K., Brannon, L. A., Shanklin, C. W., Roberts, K. R., Barrett, B. B., and Howells, A. D. (2008). Food safety training requirements and food handlers' knowledge and behaviors. Food Prot Trends, 28 (3): 192-200. http://doi.org/10.1016/j.foodcont.2015.05.002.

Porticella, N., Shapiro, M. A., and Gravani, R. B. (2008). Social barriers to safer food preparation and storage practices among consumers. Poster session presentation at the Annual Meeting of International Communication Association. Montreal, Canada. http://citation.allacademic.com/meta/p_mla_apa research_citation/2/3/2/5/8/p232589 in 
Redmond, E. C., and Griffith, C. J. (2003). Consumer food handling in the home: A review of food safety studies. J. Food Prot., 66 (1): 130-61. http://doi.org/10.4315/0362-028X$\underline{66.1 .130 .}$

Redmond, E. C., and Griffith, C. J. (2004). Consumer attitudes and perceptions towards microbial food safety in the domestic kitchen. J. Food Saf., 24 (3): 169-94. http://doi.org/10.1111/j.1745-4565.2004.tb00383.x.

Rhynard, H. T. 2001. Food safety knowledge of grocery store managers (Master's thesis, D’Youville College).

Roberts, K. R., Barrett, B. B., Howells, A. D., Shanklin, C. W., Pilling, V. K., and Brannon, L. A. (2008). Food safety training and foodservice employees' knowledge and behavior. Food Prot Trends, 28 (4): 252-60.

Safefood. Food safety - Volume 1: Food behaviours on the Island of Ireland. (2012). https://www.safefood.eu/SafeFood/media/SafeFoodLibrary/Documents/Publications/Res earch Reports/Volume-1-Final.pdf/ Accessed 29 August 2018.

Safefood. About us. (2018). https://safefood.eu/Utility/About-Us.aspx/ Accessed 2 September 2018.

Santacruz, S. Top 7 causes of food poisoning. Australian Institute of Food Safety. (2016). https://www.foodsafety.com.au/resources/articles/top-7-causes-of-food-poisoning/ Accessed 21 July 2018.

Scheule, B. (2004). Food safety education: Health professionals' knowledge and assessment of WIC client needs. J Am Diet Assoc, 104 (5): 799-803. http://doi.org/10.1016/j.jada.2004.02.025. 
Shapiro, M. A., Porticella, N., Jiang, L. C., and Gravani, R. B. (2011). Predicting intentions to adopt safe home food handling practices. Applying the theory of planned behavior. Appetite, 56 (1): 96-103. http://doi.org/10.1016/j.appet.2010.11.148.

Starke, Y., Ralston, K., Brent, C. P., Riggins, T., and Lin, C-T. J. Consumer food safety behavior: A case study in hamburger cooking and ordering. Agricultural Economics Reports, United States Department of Agriculture, Economic Research Service. (2002). https://econpapers.repec.org/RePEc:ags:uerser:34061/ Accessed 27 August 2018.

Takeuchi, M. T. (2004). Use of transtheoretical model to develop an understanding of consumer responses to a food safety intervention involving use of food thermometers (PhD thesis, Washington State University).

Takeuchi, M. T., Edlefsen, M., McCurdy, S. M., and Hillers, V. N. (2005a). Educational intervention enhances consumers' readiness to adopt food thermometer use when cooking small cuts of meat: An application of the transtheoretical model. J. Food Prot., 68 (9): 1874-83. http://doi.org/10.4315/0362-028X-68.9.1874.

Takeuchi, M. T., Hillers, V., Edwards, Z. M., Edlefsen, M., and McCurdy, S. M. (2005b). Food thermometer educational materials: 'Now you're cooking...Using a food thermometer!' J Nutr Educ Behav, 37 (5): 271-72. http://doi.org/10.1016/S14994046(06)60283-2.

Takeuchi, M. T., Edlefsen, M., McCurdy, S. M., and Hillers, V. N. (2006). Development and validation of stages-of-change questions to assess consumers' readiness to use a food thermometer when cooking small cuts of meat. J Am Diet Assoc, 106 (2): 262-66. http://doi.org/10.1016/j.jada.2005.10.036.

Teague, J. L., and Anderson, D. W. (1995). Consumer preferences for safe handling labels on meat and poultry. J Consum Aff, 29 (1): 108. http://doi.org/10.1111/j.1745- 
Tricco, A. C., Lillie, E., Zarin, W., O’Brien, K., Colquhoun, H., Kastner, M., ... Straus, S. E.2016. A scoping review on the conduct and reporting of scoping reviews. BMC Med Res Methodol, 16 (15). http://doi.org/0.1186/s12874-016-0116-4.

Unklesbay, N., Sneed, J., and Toma, R. (1998). College students' attitudes, practices, and knowledge of food safety. J. Food Prot., 61 (9): 1175-80. http://doi.org/10.4315/0362$\underline{028 X-61.9 .1175}$.

Woods, R. D. (2015). Television celebrity chefs as role models for consumer's safe food handling in the home (Master's thesis, University of California). 
consumers receiving in-person versus web based food safety training (Master's thesis).

York, V. K., Brannon, L. A., Shanklin, C. W., Roberts, K. R., Barrett, B. B., and Howells, A. D. (2009). Intervention improves restaurant employees' food safety compliance rates. Int J Contemp Hosp, M 21 (4): 459-78. http://doi.org/10.1108/09596110910955703. consumers: A systematic review and thematic synthesis of qualitative research studies. PLoS ONE, 11 (12). http://doi.org/10.1371/journal.pone.0167695. 
Tables captions:

Table 1. Safe minimum cooking temperatures for different meat types recommended by USDA- FSIS (2015a), Government of Canada (2015), and NSW Food Authority (2018)

Table 2. Summary of the findings of direct observation studies and surveys concerned with trends of thermometers ownership and usage

Table 3. Summary of trends in meat thermometers usage with different meat types

\section{Figures captions:}

Fig. 1. Flow diagram of the included studies 
Table 1. Safe minimum cooking temperatures for different meat types recommended by USDA- FSIS (2015a), Government of Canada (2015), and NSW Food Authority (2018)

\begin{tabular}{lccc}
\hline \multicolumn{1}{c}{ Meat type } & \multicolumn{3}{c}{ Safe minimum cooking temperature } \\
& US & $\begin{array}{c}\left({ }^{\circ} \mathrm{C}\right) \\
\text { Canada }\end{array}$ & NSW \\
\hline Beef, Veal, and Lamb & 62.8 & 63 & 63 \\
Pork & 62.8 & 71 & 63 \\
Ground/minced meat & 71.1 & 71 & 71 \\
Whole poultry & 73.9 & 82 & 74 \\
Ground/Pieces of poultry & 73.9 & 74 & 74 \\
Fish & 62.8 & 70 & 63 \\
\hline
\end{tabular}

3 
Table 2. Summary of the findings of direct observation studies and surveys concerned with trends of thermometers ownership and usage

\begin{tabular}{|c|c|c|c|c|c|c|c|c|c|c|}
\hline \multirow{2}{*}{$\begin{array}{l}\text { Type of } \\
\text { study }\end{array}$} & \multirow[t]{2}{*}{ Participants } & \multirow[t]{2}{*}{ Country } & \multirow{2}{*}{$\begin{array}{l}\text { Type of } \\
\text { cooked } \\
\text { food }\end{array}$} & \multicolumn{2}{|c|}{ Direct observation } & \multicolumn{3}{|c|}{ Survey } & \multirow{2}{*}{$\begin{array}{c}\text { \% relying } \\
\text { only on } \\
\text { sensory cues } \\
\text { (observation } \\
\text { or survey) }\end{array}$} & \multirow[t]{2}{*}{ Reference } \\
\hline & & & & $\begin{array}{l}\text { Cooking } \\
\text { setting }\end{array}$ & 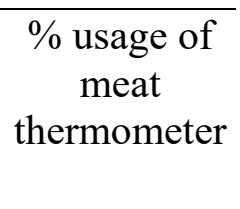 & $\begin{array}{l}\% \text { ownership } \\
\text { of meat } \\
\text { thermometer }\end{array}$ & $\begin{array}{l}\% \text { knowledge } \\
\text { of minimum } \\
\text { safe cooking } \\
\text { temperature }\end{array}$ & $\begin{array}{c}\% \text { usage of } \\
\text { thermometers }\end{array}$ & & \\
\hline $\begin{array}{c}\text { Direct } \\
\text { observation } \\
+ \text { survey }\end{array}$ & $\begin{array}{l}\text { Phone-recruited } \\
\text { adults }\end{array}$ & US & $\begin{array}{l}\text { Beef, } \\
\text { chicken, } \\
\text { or fish }\end{array}$ & $\begin{array}{l}\text { Participant's } \\
\text { home }\end{array}$ & $\begin{array}{c}5 \% \\
\text { voluntarily }\end{array}$ & $30 \%$ & $30 \%$ & N/A & $89 \%$ & $\begin{array}{c}\text { (J. B. Anderson, } \\
\text { Shuster, } \\
\text { Hansen, Levy } \\
\& \text { Volk, 2004) }\end{array}$ \\
\hline $\begin{array}{c}\text { Direct } \\
\text { observation } \\
+ \text { survey }\end{array}$ & $\begin{array}{l}\text { Adults recruited } \\
\text { via } \\
\text { advertisement }\end{array}$ & US & Burger & $\begin{array}{c}\text { Participant's } \\
\text { home }\end{array}$ & $\begin{array}{c}4 \% \\
\text { voluntarily }\end{array}$ & $53 \%$ & $35 \%$ & N/A & $75 \%$ & $\begin{array}{l}\text { (Phang and } \\
\text { Bruhn, 2011) }\end{array}$ \\
\hline $\begin{array}{c}\text { Direct } \\
\text { observation } \\
+ \text { survey }\end{array}$ & $\begin{array}{l}\text { Adults recruited } \\
\text { at shopping } \\
\text { centres }\end{array}$ & US & Chicken & $\begin{array}{l}\text { Participant's } \\
\text { home }\end{array}$ & $\begin{array}{c}<5 \% \\
\text { voluntarily }\end{array}$ & $48 \%$ & $53 \%$ & N/A & $95 \%$ & (Bruhn, 2014) \\
\hline $\begin{array}{l}\text { Web-based } \\
\text { survey }\end{array}$ & $\begin{array}{c}\text { Online } \\
\text { randomly } \\
\text { selected adults }\end{array}$ & US & Burger & N/A & N/A & $16 \%$ & N/A & $\begin{array}{c}19 \% \text { of } \\
\text { participants }\end{array}$ & $59 \%$ & (Lin, 2018) \\
\hline $\begin{array}{c}\text { Direct } \\
\text { observation } \\
+ \text { survey }\end{array}$ & $\begin{array}{l}\text { Adults recruited } \\
\text { by fliers, } \\
\text { friends and } \\
\text { family members }\end{array}$ & US & Poultry & $\begin{array}{l}\text { Participant's } \\
\text { home }\end{array}$ & $\begin{array}{c}5 \% \\
\text { voluntarily }\end{array}$ & $43 \%$ & $50 \%$ & $\begin{array}{c}25 \% \text { of } \\
\text { participants }\end{array}$ & $95 \%$ & $\begin{array}{l}\text { (Mazengia, } \\
\text { Fisk, Liao, } \\
\text { Huang, and } \\
\text { Meschke, 2015) }\end{array}$ \\
\hline
\end{tabular}




\begin{tabular}{|c|c|c|c|c|c|c|c|c|c|c|}
\hline \multirow{2}{*}{$\begin{array}{l}\text { Type of } \\
\text { study }\end{array}$} & \multirow[t]{2}{*}{ Participants } & \multirow[t]{2}{*}{ Country } & \multirow{2}{*}{$\begin{array}{l}\text { Type of } \\
\text { cooked } \\
\text { food }\end{array}$} & \multicolumn{2}{|c|}{ Direct observation } & \multicolumn{3}{|c|}{ Survey } & \multirow{2}{*}{$\begin{array}{c}\text { \% relying } \\
\text { only on } \\
\text { sensory cues } \\
\text { (observation } \\
\text { or survey) }\end{array}$} & \multirow[t]{2}{*}{ Reference } \\
\hline & & & & $\begin{array}{l}\text { Cooking } \\
\text { setting }\end{array}$ & 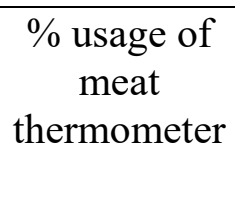 & $\begin{array}{l}\% \text { ownership } \\
\text { of meat } \\
\text { thermometer }\end{array}$ & $\begin{array}{l}\text { \% knowledge } \\
\text { of minimum } \\
\text { safe cooking } \\
\text { temperature }\end{array}$ & $\begin{array}{c}\% \text { usage of } \\
\text { thermometers }\end{array}$ & & \\
\hline $\begin{array}{c}\text { Direct } \\
\text { observation } \\
+ \text { survey }\end{array}$ & $\begin{array}{l}\text { Adolescents } \\
\text { and parents of } \\
\text { youth } \\
\text { basketball } \\
\text { teams }\end{array}$ & US & $\begin{array}{l}\text { Breaded } \\
\text { chicken }\end{array}$ & $\begin{array}{l}\text { Student food } \\
\text { preparation } \\
\text { kitchen in } \\
\text { the } \\
\text { university }\end{array}$ & $\begin{array}{c}12 \% \\
\text { (instructed } \\
\text { on package) }\end{array}$ & $73 \%$ & $43 \%$ & $\begin{array}{c}20 \% \text { of } \\
\text { participants }\end{array}$ & $37 \%$ & $\begin{array}{l}\text { (DeDonder } \\
\text { et al., 2009; } \\
\text { 2012) }\end{array}$ \\
\hline $\begin{array}{l}\text { Web-based } \\
\text { survey }\end{array}$ & $\begin{array}{l}\text { Adult grocery } \\
\text { shoppers }\end{array}$ & US & Poultry & N/A & N/A & $62 \%$ & N/A & $\begin{array}{c}26-73 \% * \text { of } \\
\text { owners }\end{array}$ & N/A & $\begin{array}{l}\text { (Kosa, Cates, } \\
\text { Bradley, } \\
\text { Chambers, } \\
\text { and Godwin, } \\
\text { 2015) }\end{array}$ \\
\hline Survey & $\begin{array}{c}\text { Seniors and } \\
\text { parents of } \\
\text { young children }\end{array}$ & US & $\begin{array}{l}\text { Beef, } \\
\text { pork, } \\
\text { burger }\end{array}$ & N/A & N/A & $42 \%$ & N/A & $\begin{array}{l}5-24 \% * \text { of } \\
\text { participants }\end{array}$ & N/A & $\begin{array}{l}\text { (Cates and } \\
\text { Anderson, } \\
\text { 1999) }\end{array}$ \\
\hline Survey & $\begin{array}{c}\text { Students of East } \\
\text { Carolina } \\
\text { University }\end{array}$ & US & $\begin{array}{l}\text { Burger } \\
\text { and fish }\end{array}$ & N/A & N/A & $23 \%$ & N/A & $\begin{array}{c}<67 \% \text { of } \\
\text { owners }\end{array}$ & N/A & $\begin{array}{c}\text { (McArthur, } \\
\text { Holbert, and } \\
\text { Forsythe III, } \\
\text { 2007) }\end{array}$ \\
\hline $\begin{array}{c}\text { Direct } \\
\text { observation } \\
+ \text { survey }\end{array}$ & $\begin{array}{l}\text { Graduates of } \\
\text { nutrition } \\
\text { education } \\
\text { program }\end{array}$ & US & $\begin{array}{l}\text { Burger } \\
\text { and } \\
\text { chicken }\end{array}$ & $\begin{array}{l}\text { Community } \\
\text { kitchens }\end{array}$ & $\begin{array}{c}16 \% \\
\text { voluntarily }\end{array}$ & N/A & N/A & N/A & N/A & $\begin{array}{l}\text { (Kendall et } \\
\text { al., 2004) }\end{array}$ \\
\hline
\end{tabular}




\begin{tabular}{|c|c|c|c|c|c|c|c|c|c|c|}
\hline \multirow{2}{*}{$\begin{array}{l}\text { Type of } \\
\text { study }\end{array}$} & \multirow[t]{2}{*}{ Participants } & \multirow[t]{2}{*}{ Country } & \multirow{2}{*}{$\begin{array}{l}\text { Type of } \\
\text { cooked } \\
\text { food }\end{array}$} & \multicolumn{2}{|c|}{ Direct observation } & \multicolumn{3}{|c|}{ Survey } & \multirow{2}{*}{$\begin{array}{c}\text { \% relying } \\
\text { only on } \\
\text { sensory cues } \\
\text { (observation } \\
\text { or survey) }\end{array}$} & \multirow[t]{2}{*}{ Reference } \\
\hline & & & & $\begin{array}{l}\text { Cooking } \\
\text { setting }\end{array}$ & $\begin{array}{c}\% \text { usage of } \\
\text { meat } \\
\text { thermometer }\end{array}$ & $\begin{array}{l}\% \text { ownership } \\
\text { of meat } \\
\text { thermometer }\end{array}$ & $\begin{array}{l}\text { \% knowledge } \\
\text { of minimum } \\
\text { safe cooking } \\
\text { temperature }\end{array}$ & $\begin{array}{l}\% \text { usage of } \\
\text { thermometers }\end{array}$ & & \\
\hline $\begin{array}{c}\text { Direct } \\
\text { observation } \\
+ \text { survey }\end{array}$ & $\begin{array}{c}\text { Sample of } \\
\text { consumers } \\
\text { distributed } \\
\text { among 2-3 } \\
\text { states }\end{array}$ & US & $\begin{array}{l}\text { Chicken } \\
\text { breast } \\
\text { and } \\
\text { turkey } \\
\text { patties }\end{array}$ & $\begin{array}{l}\text { Home style } \\
\text { kitchens }\end{array}$ & $\begin{array}{l}22-37 \% \\
\text { depending } \\
\text { on type of } \\
\text { food }\end{array}$ & $63 \%$ & N/A & $\begin{array}{c}20-30 \% \\
\text { depending on } \\
\text { type of food }\end{array}$ & $\begin{array}{c}6-22 \% \\
\text { depending } \\
\text { on type of } \\
\text { food }\end{array}$ & $\begin{array}{l}\text { (Maughan, } \\
\text { 2015) }\end{array}$ \\
\hline $\begin{array}{l}\text { Phone } \\
\text { survey }\end{array}$ & $\begin{array}{c}\text { Randomly } \\
\text { phone-recruited } \\
\text { adults of } \\
\text { different } \\
\text { ethnicities }\end{array}$ & US & Poultry & N/A & N/A & $\begin{array}{c}35-64 \% \\
\text { depending on } \\
\text { ethnicity }\end{array}$ & $20 \%$ & N/A & $53 \%$ & $\begin{array}{l}\text { (Henley, } \\
\text { Stein, and } \\
\text { Quinlan, } \\
\text { 2015) }\end{array}$ \\
\hline Survey & $\begin{array}{c}\text { Students in } 3 \\
\text { universities in } 3 \\
\text { states from food } \\
\text { and non-food } \\
\text { related majors }\end{array}$ & US & General & N/A & N/A & N/A & N/A & $\begin{array}{c}6 \% \text { of } \\
\text { participants }\end{array}$ & $91 \%$ & $\begin{array}{c}\text { (Unklesbay, } \\
\text { Sneed, and } \\
\text { Toma, 1998) }\end{array}$ \\
\hline $\begin{array}{c}\text { Direct } \\
\text { observation }\end{array}$ & $\begin{array}{l}\text { Young adults - } \\
\text { college students }\end{array}$ & US & Chicken & $\begin{array}{l}\text { Food } \\
\text { preparation } \\
\text { laboratory }\end{array}$ & $\begin{array}{c}3 \% \\
\text { voluntarily }\end{array}$ & N/A & N/A & N/A & $97 \%$ & $\begin{array}{c}\text { (Byrd- } \\
\text { Bredbenner, } \\
\text { Maurer, } \\
\text { Cottone, } \\
\text { Clancy, and } \\
\text { Wheatley, } \\
\text { 2007) }\end{array}$ \\
\hline
\end{tabular}




\begin{tabular}{|c|c|c|c|c|c|c|c|c|c|c|}
\hline \multirow{2}{*}{$\begin{array}{l}\text { Type of } \\
\text { study }\end{array}$} & \multirow[t]{2}{*}{ Participants } & \multirow[t]{2}{*}{ Country } & \multirow{2}{*}{$\begin{array}{l}\text { Type of } \\
\text { cooked } \\
\text { food }\end{array}$} & \multicolumn{2}{|c|}{ Direct observation } & \multicolumn{3}{|c|}{ Survey } & \multirow{2}{*}{$\begin{array}{c}\text { \% relying } \\
\text { only on } \\
\text { sensory cues } \\
\text { (observation } \\
\text { or survey) }\end{array}$} & \multirow[t]{2}{*}{ Reference } \\
\hline & & & & $\begin{array}{c}\text { Cooking } \\
\text { setting }\end{array}$ & 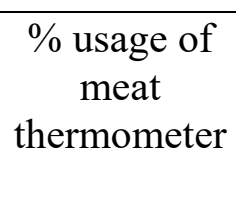 & $\begin{array}{c}\% \text { ownership } \\
\text { of meat } \\
\text { thermometer }\end{array}$ & $\begin{array}{l}\text { \% knowledge } \\
\text { of minimum } \\
\text { safe cooking } \\
\text { temperature }\end{array}$ & $\begin{array}{l}\% \text { usage of } \\
\text { thermometers }\end{array}$ & & \\
\hline Survey & $\begin{array}{l}\text { Phone-recruited } \\
\quad \text { adults in } \\
\text { Waterloo region }\end{array}$ & Canada & $\begin{array}{c}\text { Burger, } \\
\text { chicken } \\
\text { or fish }\end{array}$ & N/A & N/A & $\mathrm{N} / \mathrm{A}$ & N/A & $\begin{array}{c}14 \% \text { of } \\
\text { participants }\end{array}$ & $64 \%$ & $\begin{array}{l}\text { (Nesbitt et } \\
\text { al., 2009) }\end{array}$ \\
\hline Survey & $\begin{array}{l}\text { Phone-recruited } \\
\text { adults } \\
\text { (including high- } \\
\text { risk groups) }\end{array}$ & Canada & $\begin{array}{l}\text { Pork, } \\
\text { poultry } \\
\text { and } \\
\text { ground } \\
\text { meat }\end{array}$ & N/A & N/A & N/A & $61-63 \% *$ & $\begin{array}{c}29 \% \text { of } \\
\text { participants }\end{array}$ & $75 \%$ & $\begin{array}{c}\text { (Ekos } \\
\text { Research } \\
\text { Associates } \\
\text { Inc., 2010) }\end{array}$ \\
\hline Survey & $\begin{array}{c}\text { Phone-recruited } \\
\text { adults from all } \\
\text { Canadian } \\
\text { provinces }\end{array}$ & Canada & $\begin{array}{l}\text { Pork, } \\
\text { poultry } \\
\text { and fish }\end{array}$ & N/A & N/A & N/A & $53 \%$ & $\begin{array}{c}29 \% \text { of } \\
\text { participants }\end{array}$ & $65 \%$ & $\begin{array}{c}\text { (Murray et } \\
\text { al., 2017) }\end{array}$ \\
\hline Survey & $\begin{array}{c}\text { Undergraduate } \\
\text { University } \\
\text { students }\end{array}$ & Canada & $\begin{array}{c}\text { Meat } \\
\text { and } \\
\text { chicken }\end{array}$ & N/A & N/A & N/A & $\mathrm{N} / \mathrm{A}$ & $\begin{array}{c}21 \% \text { of } \\
\text { participants }\end{array}$ & $\mathrm{N} / \mathrm{A}$ & $\begin{array}{c}\text { (Courtney, } \\
\text { 2017) }\end{array}$ \\
\hline Survey & $\begin{array}{l}\text { Phone-recruited } \\
\text { residents in } \\
\text { Vancouver area }\end{array}$ & Canada & $\begin{array}{l}\text { Burger } \\
\text { and } \\
\text { chicken } \\
\text { breasts }\end{array}$ & N/A & N/A & N/A & $\mathrm{N} / \mathrm{A}$ & $\begin{array}{l}14-18 \% * \text { of } \\
\text { participants }\end{array}$ & N/A & $\begin{array}{c}\text { (Fraser } \\
\text { Health and } \\
\text { Vancouver } \\
\text { Coastal } \\
\text { Health, } \\
\text { 2010) }\end{array}$ \\
\hline
\end{tabular}




\begin{tabular}{|c|c|c|c|c|c|c|c|c|c|c|}
\hline \multirow{2}{*}{$\begin{array}{l}\text { Type of } \\
\text { study }\end{array}$} & \multirow[t]{2}{*}{ Participants } & \multirow[t]{2}{*}{ Country } & \multirow{2}{*}{$\begin{array}{l}\text { Type of } \\
\text { cooked } \\
\text { food }\end{array}$} & \multicolumn{2}{|c|}{ Direct observation } & \multicolumn{3}{|c|}{ Survey } & \multirow{2}{*}{$\begin{array}{l}\text { \% relying } \\
\text { only on } \\
\text { sensory cues } \\
\text { (observation } \\
\text { or survey) }\end{array}$} & \multirow[t]{2}{*}{ Reference } \\
\hline & & & & $\begin{array}{l}\text { Cooking } \\
\text { setting }\end{array}$ & $\begin{array}{c}\% \text { usage of } \\
\text { meat }\end{array}$ & $\begin{array}{c}\% \text { ownership } \\
\text { of meat } \\
\text { thermometer }\end{array}$ & $\begin{array}{l}\text { \% knowledge } \\
\text { of minimum } \\
\text { safe cooking } \\
\text { temperature }\end{array}$ & $\begin{array}{c}\% \text { usage of } \\
\text { thermometers }\end{array}$ & & \\
\hline Survey & $\begin{array}{c}\text { Consumers } \\
\text { interviewed in } \\
\text { central London } \\
\text { and } \\
\text { Bexleyheath }\end{array}$ & UK & $\begin{array}{c}\text { Meat } \\
\text { and fish }\end{array}$ & N/A & N/A & N/A & $\mathrm{N} / \mathrm{A}$ & $\begin{array}{c}4 \% \text { of } \\
\text { participants }\end{array}$ & $91 \%$ & $\begin{array}{c}\text { (Bates, } \\
\text { Hovard, Sal, } \\
\text { and Eaton, } \\
\text { 2017) }\end{array}$ \\
\hline Survey & $\begin{array}{l}\text { Randomly } \\
\text { selected } \\
\text { households }\end{array}$ & Ireland & $\begin{array}{l}\text { Meat } \\
\text { and } \\
\text { poultry }\end{array}$ & N/A & N/A & N/A & N/A & $\begin{array}{c}2 \% \text { of } \\
\text { participants }\end{array}$ & $80 \%$ & $\begin{array}{l}\text { (Kennedy et } \\
\text { al., 2005) }\end{array}$ \\
\hline Survey & $\begin{array}{l}\text { Phone-recruited } \\
\text { adults }\end{array}$ & Ireland & Beef & N/A & N/A & N/A & N/A & $\begin{array}{c}3 \% \text { of } \\
\text { participants }\end{array}$ & $83 \%$ & $\begin{array}{l}\text { (Mahon, } \\
\text { Cowan, } \\
\text { Henchion, } \\
\text { and Fanning, } \\
\text { 2006) }\end{array}$ \\
\hline $\begin{array}{c}\text { Direct } \\
\text { observation } \\
+ \text { survey }\end{array}$ & $\begin{array}{l}\text { Recruited by } \\
\text { advertisement }\end{array}$ & Austria & Chicken & $\begin{array}{c}\text { Participants' } \\
\text { home }\end{array}$ & $3 \%$ & N/A & N/A & N/A & $78 \%$ & $\begin{array}{l}\text { (Hoelzl et } \\
\text { al., 2013) }\end{array}$ \\
\hline Survey & $\begin{array}{l}\text { Nationally } \\
\text { selected adult } \\
\text { participants }\end{array}$ & Netherlands & $\begin{array}{c}\text { Meat } \\
\text { and } \\
\text { chicken }\end{array}$ & N/A & N/A & N/A & N/A & $\begin{array}{c}11 \% \text { of } \\
\text { participants }\end{array}$ & N/A & $\begin{array}{l}\text { (Fischer, } \\
\text { Frewer, and } \\
\text { Nauta, 2006) }\end{array}$ \\
\hline
\end{tabular}

$1 *$ Different percentages depending on type of food 
Table 3. Summary of trends in meat thermometers usage with different meat types

\begin{tabular}{|c|c|c|}
\hline Meat type & Percentage of usage & Reference \\
\hline Whole poultry & $24 \%$ & (Cates and Anderson, 1999) \\
\hline Whole chicken & $33-57 \%$ & (Kosa et al., 2015; Murray et al., 2017) \\
\hline Whole turkey & $42-73 \%$ & (Kosa et al., 2015; Murray et al., 2017) \\
\hline Roasts & $21-38 \%$ & (Cates and Anderson, 1999; FDA, 2016; Murray et al., 2017) \\
\hline Chicken parts & $18-37 \%$ & (Maughan, 2015; FDA, 2016; Fraser Health and Vancouver Coastal Health, 2010) \\
\hline Turkey patties & $22 \%$ & (Maughan, 2015) \\
\hline Ground poultry & $23 \%$ & (Kosa et al., 2015) \\
\hline Hamburger, ground meat & $5-14 \%$ & (Cates and Anderson, 1999; FDA, 2016; Fraser Health and Vancouver Coastal Health, 2010; Murray et al., 2017) \\
\hline Fish & $3.5 \%$ & (Murray et al., 2017) \\
\hline \multicolumn{3}{|l|}{3} \\
\hline \multicolumn{3}{|l|}{4} \\
\hline \multicolumn{3}{|l|}{5} \\
\hline 6 & & \\
\hline
\end{tabular}


1 Fig. 1. Flow diagram of the included studies

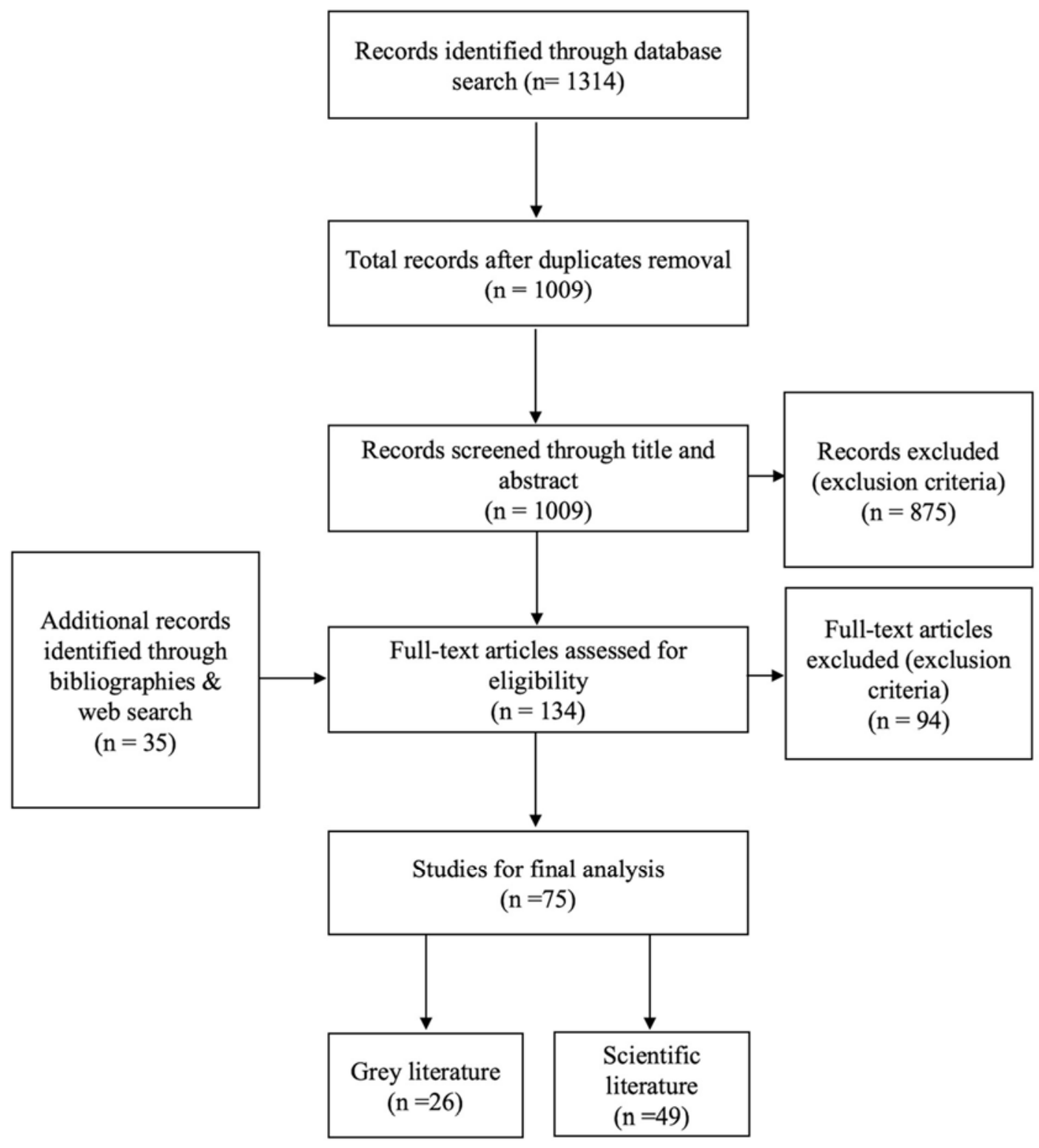

